\title{
Las Tecnologías de la Información y el aporte a la investigación de políticas educativas: la aplicación del SIG a escuelas de EGB3 de la ciudad de Paraná
}

\author{
Virginia Kummer (1), Gabriela Andretich (2), Andrea \\ Hernán, Julia Osella, Carina Cabrol y Bárbara Correa
}

\author{
Palabras clave: \\ planeamiento educativo - vulnerabilidad . \\ Sistemas Informáticos Georreferenciados - EGB 3 . \\ democratización de la información
}

Resumen. Este trabajo presenta los resultados de un proyecto interdisciplinario - conjuga aportes provenientes de la Estadística y el Planeamiento de la Educación-y considera que la democratización de la información puede ser un pilar para la toma de decisiones compartidas en materia de política educativa. De carácter exploratorio-descriptivo, el proyecto propuso la integración de diversas fuentes y la utilización de software espacial (Sistema de Información Georreferencial) para un análisis situacional aplicado al caso de escuelas de EGB3 del departamento Paraná, provincia de Entre Ríos. Los resultados obtenidos permiten dar cuenta del modo en el cual la relación estrecha que se establece entre los mapas digitales y la información asociada a los elementos gráficos contenidos en bases de datos da una nueva dimensión al tratamiento de la información. Sin embargo, la utilización de un sistema como el SIG debe hacerse sin caer en determinismos metodológicos. En el caso que se presenta, la información cuantitativa se combinó con el trabajo en terreno y la escucha de los actores involucrados en la problemática.
Keywords:

teacher training - Language and Literature Didactics . action rules $\cdot$ didactic recipe

Abstract. Over the last years, Language and Literature Didactics has given up the task of offering action rules for teaching by taking one of these two ways: on the one hand, it has chosen the way of "theoretical flight", which had been first taken by General Didactics; on the other, driven by Ethnography, it has headed towards "experientialism": spreading narratives of classroom experiences developed in specific contexts. Both ways have one point in common: they both have quit making proposals for teaching, which should be an important part of teacher training instead. It's usually rejected because it's considered as "making recipes", though.

With regard to this situation, this article at first analyzes the viewpoint that actually denies general action rules method (the "anti-recipe" stance), which can be viewed in a context of one debate on a particular proposal that was directed at the group of high school literature teachers. Secondly, the possibility of recovering the concept of "pedagogic recipe" is analyzed in order to transfer it to the teacher training field by translating it as "didactic recipe". 